\title{
miR-155 as a diagnostic and prognostic marker in hematological and solid malignancies
}

\section{Minireview}

D. JURKOVICOVA ${ }^{1, \star}$, M. MAGYERKOVA ${ }^{1}$, L. KULCSAR ${ }^{1}$, M. KRIVJANSKA $^{1}$, V. KRIVJANSKY ${ }^{1}$, A. GIBADULINOVA ${ }^{2}$, I. OVECKOVA ${ }^{2}$, M. CHOVANEC $^{1,3}$

${ }^{1}$ KRD Molecular Technologies Ltd., Saratovská 26, 84201 Bratislava, Slovakia; ${ }^{2}$ Institute of Virology, Slovak Academy of Sciences, Dúbravská cesta 9, 84104 Bratislava, Slovakia; ${ }^{3}$ Cancer Research Institute, Slovak Academy of Sciences, Vlárska 7, 83391 Bratislava, Slovakia

${ }^{*}$ Correspondence: dana.j@krdlab.sk

Received October 2, 2013 / Accepted November 6, 2013

\begin{abstract}
MicroRNAs (miRNAs) are small RNAs that have emerged as potent regulators of the target genes messenger RNAs expression in the response of cell to both physiological and pathophysiological conditions. Reflecting pathological processes today, miRNAs are widely validated for their potential role in diagnostic, prognostic and novel therapeutic targeting for cancerous and other diseases. miR-155 is considered as a typical multifunctional miRNA including its role as oncomiR (cancer-associated miRNA). Expression of miR-155 is upregulated in cells with high proliferative activity and decreased apoptotic capability. It belongs to cluster of well-characterized tumor associated miRNAs detectable also in the peripheral blood. In this review we summarize the principles of miR-155 host gene expressional regulation, as well as its role in regulation of the target genes mRNAs. Altered expression of miR-155 has been described in multiple cancerous and other diseases, reflecting staging, progress and treatment outcomes. Therefore, miR-155 became a potential biomarker and candidate for clinical utilization as predictor of the presence of cancer, its staging and prognosis.
\end{abstract}

Key words: miR-155, gene expression regulation, carcinogenesis, diagnosis, prognosis, therapy

MicroRNAs (miRNAs) are non-coding, small (20-25 nts) single-stranded RNAs that regulate the gene expression in cell development [1], proliferation [2] and differentiation [3], apoptosis [4], immune response, inflammation [5], viral infection [6], as well as in pathological states as autoimmune, cancerous [7] and other diseases [8].

miRNA post-transcriptionally regulate the gene expression [9] by binding to 3 untranslated regions (3'-UTRs) of the target mRNAs. They recruit the RNA-induced silencing complex (RISC) to repress their expression or degrade target mRNA [10]. miRNAs constitute only $1-3 \%$ of the human genome and they regulate the expression of approx. $60 \%$ of all protein coding genes in humans [11]. Each miRNA can affect numerous target mRNAs [9] and each mRNAs can be targeted by multiple miRNAs, enabling wide regulatory complexity of gene expression adjustment $[12,13]$.
miRNAs originate from independent miRNA genes or they are matured from the intronic regions of protein-coding $\mathrm{mR}$ NAs [14] along with their host genes. In the nucleus primary miRNA (pri-miRNA) is produced, capped and polyadenylated. After transcription, pri-mRNA is processed by Drosha and its cofactor DGCR8 (DiGeorge syndrome critical region gene 8) into precursor miRNA (pre-miRNA) loosing 5' cap, the 3' poly (A) tail and the hairpin structure. Further, Exportin 5 exports pre-miRNA from nucleus to cytoplasm [13], where it is processed by Dicer-endoribonuclease, with its co-factor TRBP (trans-activating response RNA-binding protein 2, TARBP2), and RNA duplexes of $\sim 22$ nucleotides [14] are produced. Duplexes consist of the mature and its complementary miRNA strand. Afterwards, an Argonaute (Ago) protein binds to the short RNA duplexes and form complex - miRNA-induced silencing complex (miRNA/RISC) [15]. One of the two 
strands, the "passenger miRNA" (complementary "miRNA*"), is released and degraded while the other strand, designated the "guide strand" or "mature miRNA," is retained within miRNA/RISC [16]. But lately both arms of the pre-miRNA hairpin were shown to give rise to mature miRNAs [17]. According to nomenclature purposes, these products are now denoted with the suffix $-5 \mathrm{p}$ : e.g. miR-155-5p (from the 5 arm) or -3p: miR-155-3p (from the 3 arm) [18]. Expression levels of miRNAs are tightly controlled by both transcriptional and post-transcriptional mechanisms [19].

The mature miRNA is assembled into the miRNA/RISC complex, recognizes its target mRNAs by base pairing miRNA seed region (nucleotides 2-8) and complementary nucleotides mostly in the 3'-UTR of the target mRNAs $[11,20]$. A complexbound mRNAs are subjected to translational repression or rather degradation $[21,22,15]$.

miR-155 is a typical multifunctional miRNA involved in numerous biological processes including hematopoiesis, inflammation and immunity. Deregulation of miR-155 has been found associated with different kinds of cancer, cardiovascular diseases and viral infections.

In present minireview, we present evidence that miR-155 is over-expressed in a number of neoplastic diseases and that it plays a significant role in the process of carcinogenesis. Understanding biological activity of miR-155, its gene expression and target genes regulation provides wide platform for utilization of miR-155 (together with other miRNAs) as biomarker for diagnosis of cancerous disease, its staging, progression and prognosis.

\section{Origin of miR-155}

miR-155 originates from its host gene BIC/MIR155HG. It was originally identified as B-cell Integration Cluster $(B I C)$ - the gene that was transcriptionally activated by promoter insertion at a common retroviral integration site in B-cell lymphomas. BIC shows strong sequence homology among human, mouse and chicken, and is highly expressed in lymphoid organs implying an evolutionary conserved function. The human homolog of the BIC gene consists of three exons that span a $13 \mathrm{~kb}$ region within human chromosome 21 (Hsa21) [23]. miR-155-5p and miR-155-3p strands are generated from BIC and they differently participate on post-transcriptional regulation of their target gene mRNAs. While miR-155-5p plays a major regulatory role, miR-155-5p-3p, a passenger strand, promotes the accurate processing of its partner miR-155-5p [24]. It is suggested that passenger strands are evolutionarily conserved and also have inhibitory activity $[25,26]$. Its expression levels are usually very low and its biological relevance is questionable [27], with some studies suggesting that miR155-3p can also be functional [28]. For example, in human plasmacytoid dendritic cells (PDCs) miR-155-3p expression is induced earlier in TLR7 (Toll-like receptor 7) stimulation than that of miR-155-5p, suggesting their co-operative involvement in PDC activation. In these cells, miR-155-3p positively regulated IFN- $\alpha / \beta$ (interferon $\alpha / \beta$ ) production by targeting interleukin-1 receptor-associated kinase 3 (IRAK3) mRNA for degradation, while miR-155-5p played a negative role in IFN- $\alpha / \beta$ production by targeting TGF- $\beta$ (transforming growth factor $\beta$ ) activated kinase 1/MAP3K7 (mitogen-activated protein kinase kinase kinase 7) binding protein 2 (TAB2) mRNA for degradation [29]. In human primary astrocytes, cytokines and TLR ligands induced significantly higher expression of miR-155-3p compared to miR-155-5p. In contrast, adenoviral-mediated expression of the anti-inflammatory interferon regulatory factor 3 (IRF3) protein resulted in decreased levels of both miR-155-5p and $-3 p$ in astrocytes. This data points on potential novel pro-inflammatory role of miR-155-5p and miR-155-3p [28]. miR-155 is expressed in a number of tissues and cell types and plays a critical role in a variety of biological processes. In normal physiological conditions, miR-155 plays a role in hematopoiesis, inflammation and immune responses $[30,31]$, and it is also an essential molecule in the control of both myelopoiesis and erythropoiesis [32, 33]. Expression of miR-155 was detected for the first time in B-cells, T-cells, monocytes and granulocytes [34]. Using qPCR, the highest levels of miR-155 were demonstrated in thymus and the lowest levels in liver [35]. In pathophysiological conditions, the expression of miR-155 is usually increased. Stanczyk and co-workers [36] have shown that miR-155 is over-expressed in synovial fibroblasts and monocytes of rheumatoid joints. Elevated miR-155 levels have been described in a broad array of cancers including lymphomas, leukemia and solid tumors, suggesting significant role in development of carcinogenesis acting as an oncogenic miRNA - oncomiR.

\section{MIR155HG transcriptional regulation in carcinogenesis}

Transcriptional regulation of $M I R 155 H G$ and its oncogenic properties depend on composition of the response elements present in the promoter region of MIR155HG (Fig. 1). Its regulation is ruled by multiple signaling pathways.

First miR-155 oncogenic features were demonstrated in breast cancer cells. Up-regulation of MIR155PHG was described as a consequence of activation of TGF $\beta /$ Smad signaling cascade involving Smad response element (position - 454 nt from transcription start site) and resulting in increased cell migration and invasion [37].

MIR155HG transcription is also modulated by transcription factors JunB, FosB and eventually c-Fos, that bind to conserved AP-1 element (activator protein 1 element, at position - $40 \mathrm{nt}$ ) present in the MIR155PHG promoter region. AP-1 element is important for B-cell activation, as shown in Epstein-Barr virus (EBV) - negative Burkitt lymphoma cell line [38]. In EBV-infected B-cells displaying type III latency, but not in EBV-infected cells displaying type I latency, over-expression of pri-miR-155 and miR-155-5p was described $[39,40]$. miR-155$5 p$ plays an important role during B-cell immortalization [41]. Inhibition of miR-155 decreased proliferation and increased apoptosis in EBV-positive B-cell lines [41]. 


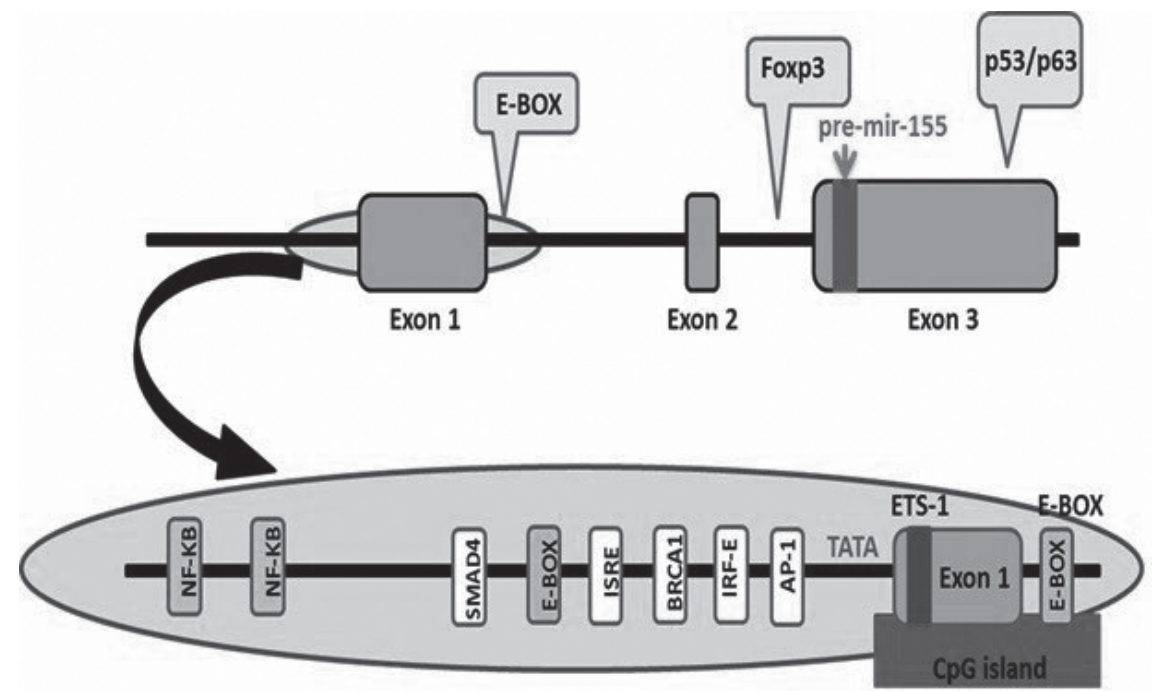

Figure 1. Transcription factor binding sites of the human MIR155HG localized upstream and just downstream of exon 1 . The dark grey area represents a CpG island. TATA represents the location of the TATA box for MIR155PHG.

In addition, $M I R 155 H G$ gene expression can be activated by transcription factors of the NF- $\mathbf{k B}$ pathway (nuclear factor $\kappa B$ pathway) [42]. As established by ChIP (chromatin immunoprecipitation) analysis, nuclear factor $\mathrm{\kappa B}$ can alternatively bind to promoter sites at position -1150 and/or $-1697 \mathrm{nt}$, (NF-kB p50/p65 complex) and activate gene transcription. P38/MAPK (p38 mitogen-activated protein kinase) signaling pathway can also stimulate MIR155PHG promoter. A critical role for the AP-1 site and a minor role for NF- $\mathrm{KB}$ have been established using the wild-type, NF- $\mathrm{KB}$ mutant, and AP-1 mutant MIR155HG reporter plasmids and JY cells (an EBVimmortalized B-cell lymphoblastoid cell line) [38].

Wang and colleagues [43] showed that interferon regulatory factors (IRFs) are also involved in MIR155HG induction by EBV-associated B-cell lymphomas displaying type III latency. Transcription factor binding site analyses of the human MIR155HG promoter region identified two putative IRF binding sites, both of which being functional in the reporter assays. ChIP experiments utilizing IB4 cells (EBV-transformed B-cell line) validated that endogenous IRF-4 and -7 can bind to the ISRE (interferon-sensitive response element) and IRFE (interferon regulatory factor element) harbored in the MIR155HG promoter in vivo [43]. These investigators demonstrated that IRF-4 negatively modulates endogenous INPP5D (inositol polyphosphate-5-phosphatase, i.e. SHIP1) levels (a miR-155-5p target) $[44,45]$ through the up-regulation of pri-miR-155 expression in EBV- or HTLV1-infected cells, providing evidence for a novel molecular mechanism underlying the IRF/MIR155HG pathway in viral oncogenesis.

Recently, Vargova et al. [46] have demonstrated that the MIR155HG promoter harbors another response element modulating MIR155HG expression. Since miR-155-5p levels were significantly higher in MYB (v-Myb myeloblas- tosis viral oncogene homolog) overexpressing B-cell chronic lymphocytic leukemia (B-CLL) patient cells, these authors hypothesized that this transcription factor may directly regulate the expression of MIR155HG. Three putative MYB binding sites (enhancer E-box elements) were identified. ChIP analyses established that this protein was consistently recruited to broad domains containing the multiple putative MYB binding sites only in primary B-CLLs. H3K9 (lysine 9 of histone H3) acetylation and H3K4 (lysine 4 of histone H3) trimethylation, both well-known markers of actively transcribed genes modifications were significantly elevated in the MIR $155 H G$ promoter regions in B-CLLs when compared to normal $\mathrm{B}$ cells. MYB stimulation of the MIR $155 H G$ promoter results in dysregulation of its epigenetic status and elevates levels of miR-155-5p. The overexpression of miR-155-5p results in the down-regulation of PU.1 and, as a consequence, the low levels of this protein may be implicated in leukemogenesis [46]. Biological activity of miR-155-5p regulation can be explained by several mechanisms.

\section{Role of miR-155-5p in hematological malignancies development and progression}

miR-155-5p is a well-studied miRNA that is closely related to the development of hematopoietic cell. Several studies have established that pri-miR-155 and miR-155-5p are highly elevated in human B-and T-cell acute lymphoblastic leukemia, B-cell chronic lymphocytic leukemia (B-CLL), acute myeloid leukemia (AML), diffuse large B-cell lymphoma (DLBCL), Hodgkin and non-Hodgkin lymphoma, primary mediastinal B-cell lymphoma (PMBL), and a number of leukemia and lymphoid cell lines [47, 48, 49, 34, 50, 51, 52, 53]. Important 
regulatory role of miR-155-5p is presented not only in origin and development of malignancy but relates also to aggressiveness and therapeutically resistance in hematological malignancies, as it participates on expressional regulation of fundamental hematopoietic oncogenes as well as tumor suppressor genes. The targets of upregulated mir-155-5p include hematopoietic transcription factor PU.1 [42, 54]. The regulatory role of miR-155-5p has been shown mostly pronounced in pathogenesis of B-CLL and DLBCL

B-cell chronic lymphocytic leukemia (B-CLL). In BCLL, the most common adult leukemia, several microRNAs deregulation was repeatedly described $[55,56]$. B-CLL is characterized by clonal accumulation of B cell-like matureappearing elements (> 5000/ $\mu \mathrm{L})$ [57] typically co-expressing the CD5, CD19, CD20, and CD23 surface markers. miR155-5p appears to play a central role in B-cell function, and it's up-regulation in lymphoproliferative disorders, including B-CLL, may lead to a block of differentiation and accumulation of lymphoid-like cells. Also, experiments on transgenic mice over-expressing miR-155-5p in B-cells showed that these mice developed pre-B-cell lymphoproliferative disorders with later progress to full B-cell lymphomas [2]. miR-155-5p is accounted for the most potent miRNA suppressing apoptosis in human T-cell leukemia of Jurkat cell line and in MDA-MB-453 human breast carcinoma cells. One explanation of its regulatory effect is blockade of Caspase-3 [58]. Overexpression of miR-155-5p is followed by down-regulation of p53-induced nuclear protein 1 (TP53INP1) that is capable of cell cycle arrest and induction of apoptosis [59]. This role in apoptosis is considered for oncogenic features of miR-155-5p in several carcinoma types.

Diffuse large B-cell lymphoma (DLBCL). In pathogenesis of DLBCL, miR-155-5p is deeply involved in multiple ways. DLBCL cells are characterized by overexpression of miR155-5p [49]. It has recently been shown that mice carrying a mutation in the 3-UTR binding sequence of miR-155-5p in the activation-induced cytidinedeaminase (AICDA) gene, a key regulator of somatic hypermutation in the germinal center, resulted in an increase in AICDA protein and can increase the levels of $\mathrm{Myc}-\mathrm{IgH}$ translocations, the characteristic genetic hallmark of B-cell lymphoma [60]. Mice that overexpress AICDA do not develop lymphoma [61]. Interestingly, AICDA is also targeted by miR181 [62], an independent prognostic indicator of survival in R-CHOP (drug combination of rituximab, cyclophosphamide, doxorubicin, vincristine, prednisolone) treated DLBCL patients [63]. Rai et al. [64] demonstrated that miR-155-5p directly targets SMAD5 and its ectopic expression suppressed the in vitro growth inhibitory effects of TGF- $\beta 1$ and BMP2/4 (bone morphogenetic protein $2 / 4$ heterodimer) in DLBCL cells. miR-155-5p can also regulate the PIK3CA-AKT1 (alpha serine/threonine specific protein kinase) pathway via direct targeting of the negative regulator PIK3R1 in DLBCL [65]. miR-155-5p has been shown by to target also Src homology-2 domain-containing inositol 5-phosphatase 1 (INPP5D) (also known as SHIP1) [45, 66].
Overexpression of miR-155-5p was found to promote $\mathrm{TNFa}$ (tumor necrosis factor $\alpha$ ) -dependent growth of DLBCL cells both in vitro and in vivo xenotransplant models via direct modulation of INPP5D levels [66]. Interestingly, CD10, a wellknown marker of germinal center B-cell (GCB)-like -type DLBCL, and constitutive expression of NF- $\mathrm{kB}$, a hallmark of activated B-cell (ABC)-type DLBCL [67], have been linked via a miR-155-5p/SPI1 (spleen focus forming virus proviral integration oncogene, PU.1) pathway [52]. In DLBCL pathogenesis miR-155 participates on expressional modulation of multiple target genes mostly related to cellular growth.

\section{Role of miR-155-5p in solid tumors development and progression}

Besides hematological malignancies, overexpression of miR-155-5p was also found in various solid tumors, including breast cancer $[68,69,70]$, colon cancer [70] and pancreatic ductal adenocarcinoma [71, 72]. Upregulated mir-155-5p expression was described also in cervical [73], lung [74, 70] and thyroid carcinoma [75].

Breast cancer. Upregulated miR-155-5p expression in breast tumors associates with the promotion of tumorigenesis [76]. Recently, Changs et al. [77] established that overexpression of miR-155-5p was triggered by mutation of BRCA1 (breast cancer 1, early onset). BRCA1 is a well-known tumor suppressor that is involved in DNA damage response and repair and plays a role in regulating transcription through interactions with histone deacetylase complexes (HDACs) [78]. The R1699Q variant of BRCA1 (arginine to glutamine amino acid change at position 1699 in the BRCA1 protein) has been associated with predisposition to breast cancer, and mouse embryonic stem cells expressing this mutant protein were found to have high levels of miR-155-5p [77]. In human cell lines deficient in BRCA1, miR-155-5p levels were upregulated 50 -fold compared to cells with functional BRCA1. Sequence analysis of the mouse MIR155PHG promoter identified two regions (the first site is conserved in humans) with putative BRCA1-binding sites, and ChIP experiments established that both sites were able to recruit BRCA1, suggesting that both sites played a role in repressing promoter activity. The binding of R1699Q BRCA1 to the MIR155HG promoter was comparable to wild-type, signifying that this protein may recruit other transcriptional repressors. Cells expressing functional BRCA1 treated with HDAC inhibitors upregulated the expression of miR-155-5p, suggesting that the MIR155PHG promoter is epigenetically controlled. ChIP analysis demonstrated that in BRCA1-deficient cells $\mathrm{H} 2 \mathrm{~A}$ and $\mathrm{H} 3$ were more acetylated, and HDAC2 was recruited to MIR155HG promoter in cells expressing wild-type BRCA1 signifying that BRCA1 negatively controls this promoter by decreasing the acetylation of $\mathrm{H} 2 \mathrm{~A}$ and H3. Finally, the knockdown of miR-155-5p in BRCA1deficient cells by a miR-155-5p binding site-sponge led to a reduction in tumor growth, suggesting that miR-155-5p is 
a potential therapeutic target for BRCA1-deficient tumors [77].

Neilsen and co-workers [79] suggested that MIR155HG may be a downstream target of the mutant $\mathrm{p} 53$, given that mutant p53 and miR-155-5p expression are both associated with invasive properties in vivo [80]. miR-155-5p expression levels were significantly higher in breast tumors with $\mathrm{p} 53$ mutations compared to those of the wild-type p53 [79]. Since mutant p53 can sequester p63 [81, 82], transcription of MIR155HG is no longer repressed and the levels of miR-155-5p would be aberrantly high and would drive invasion and metastasis. In p53 mutants, ZNF652 (a novel zinc-finger protein 652 transcriptional repressor) expression is decreased in primary breast tumors and correlates with increased invasion and metastasis, in part due to the ability of exogenous TGF- $\beta$ to activate SMAD proteins. In support of this observation, Kong et al. found that TGF- $\beta$ induced MIR155HG expression after the binding of $S \operatorname{mad} 4$ to the promoter region. These data suggest that miR-155-5p may play an important role in TGF- $\beta$ mediated epithelial-mesenchymal transition and cell migration and invasion by directly targeting RhoA (ras homolog family member A) [37].

In contrast, FOXP3 (forkhead box P3) activation of MIR155HG expression in normal epithelia may actually prevent the transformation of the healthy breast epithelium to a cancerous phenotype [83]. FOXP3 has been identified as a tumor suppressor in the breast and prostate epithelia [84] and this transcription factor can directly repress the expression of the ERBB2 (v-erb-b2 erythroblastic leukemia viral oncogene homolog 2) and the SKP2 (S-phase kinase-associated protein
2) oncogenes [85]. FOXP3 directly suppressed the expression of the oncogene SATB1 (Special AT-rich binding protein-1) and activated MIR155HG levels. Further, the SATB1 3-UTR harbors miR-155-5p binding site and this miRNA could downregulate the expression of this oncogene [83] (Fig. 2).

Colorectal carcinoma (CRC). Overexpression or downregulation of a subset of miRNAs have also been described in colorectal cancer and potential role of miR-155 was suggested too $[86,87]$. In CRC, mir-135b is the most abundantly overexpressed miRNA. Shibuya and colleagues [88] presented that miR-155-5p and miR-21 also importantly relate to diagnostics and prognostics of CRC. Their targets, PDCD4 (programmed cell death protein 4) and TP53INP1 genes, were analyzed by qRT-PCR. High levels of miR-21 were associated by vein invasion of CRC, metastasis in liver and clinical tumor stage. Increased levels of miR-155-5p were associated with metastasis in lymphatic system. Patients with higher level of miR-21 or miR-155-5p showed shorter overall survival and disease free survival. The expression of target mRNAs negatively correlated with the level of miR-21 and miR-155-5p, suggesting their potential role as prognostic biomarkers.

Pancreatic carcinoma (PaC). Singh et al. [89] described the role of miR-155-5p and its deregulation in $\mathrm{PaC}$ as important point of ROS generation (reactive oxygen species) and responsiveness to hypoxia sensitization via regulation of $\mathrm{O}_{2}$ sensor and transcription factor HIFla (hypoxia inducible factor 1).

There is growing evidence and accumulating data proving important regulatory involvement of miR-155-5p in the development and progression of tumorigenesis of many human tissues.

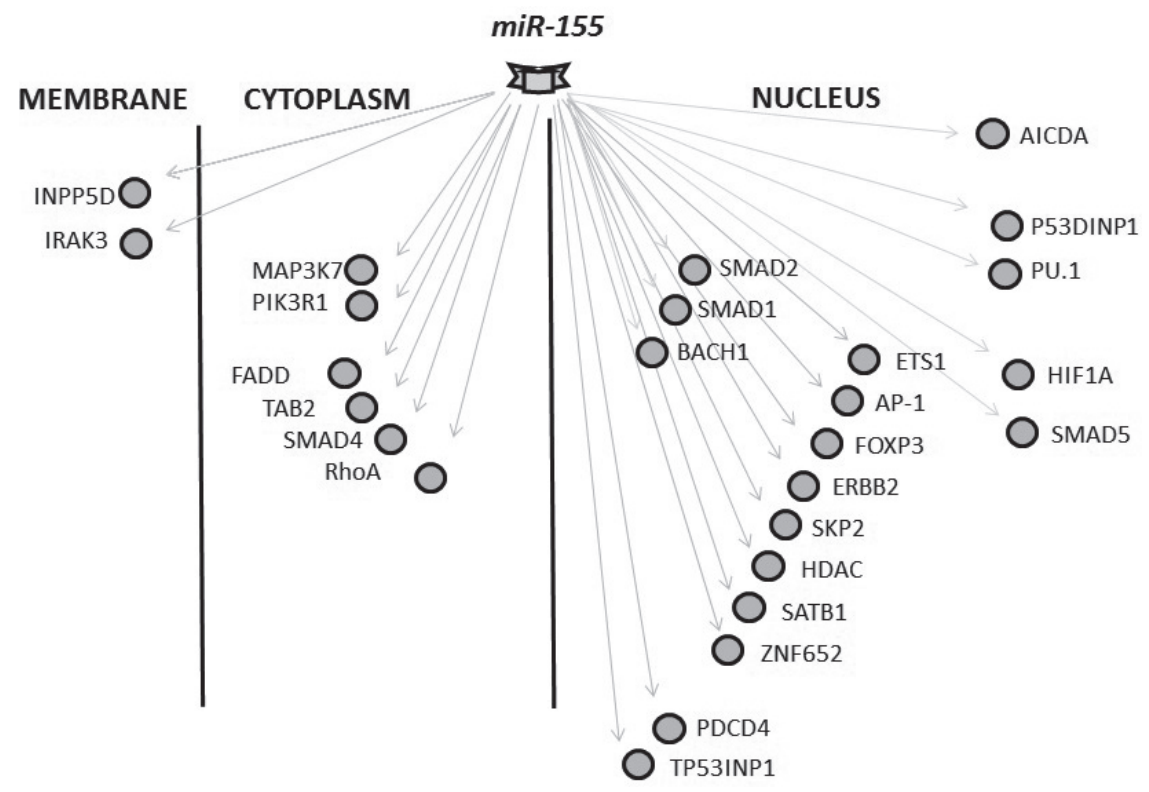

Figure 2. Schematic view of miR-155 targets. Target genes modulated by miR-155 in malignant development and progression are included in group of transcription factors located in nucleus (e.g. PU.1), kinases in cytoplasm (e.g. MAP3K7), binding proteins (e.g. SATB1), membrane bound proteases (e.g. INPP5D), and proteases, kinases and enzymes in cytoplasm. 


\section{miR-155 - controlled target genes}

Computational predicted miR-155/mRNA targets are not necessarily restricted to a particular functional category or biological pathway $[9,90]$. It is important to note that the total number of miR-155-5p putative binding sites is greater than the presumed number miR-155-5p/mRNA targets since some of the mRNAs harbor multiple miR-155 binding sites. mRNA target validation remains a critical step in defining the functions of individual miRNAs [91]. Recently, Neilsen and co-workers [92] assembled a comprehensive list of miR-155-5p/mRNA targets from the literature which were experimentally authenticated by both the demonstration of endogenous transcript regulation by miR-155-5p and validation of the miR-155-5p seed sequence through a reporter assay. This list was comprised of 140 genes and includes regulatory proteins for myelopoiesis and inflammation and known tumor suppressors $[92,93]$. From point of view of functional diversity, miR-155 target genes constitute groups of transcriptional factors, receptor ligands, G - protein coupled receptors, receptors with kinase activity, proteases, kinases and enzymes, etc. (Fig. 2). Given that miR-155-5p plays an important role in many biological pathways, futher studies are needed to fully define the in vivo mRNA targets of this miRNA.

\section{Conclusion}

Dysfunctional miRNA-mediated regulation has been implicated in the pathogenesis of many diseases. Selected miRNAs has been shown to be associated with lymph node positivity, the development of distant metastases and advanced tumor, node, metastasis staging. Increased miRNAs expression is also correlated with shorter disease-free interval and poor therapeutic outcome. Understanding the expressional patterns of miRNAs enables their utilization therapeutically, i.e. for diagnosis, prognosis and target therapy $[94,95]$. Prognostic and biological roles of miR- 155 have been evaluated in individual studies and meta-analyses. Relevant works are listed in Tab. 1, including selected adopted information from meta-analysis of He and coworkers [96]. These authors summarize eligible studies and show that higher expression of miR-155 is associated with poor survival in patients with diverse types of cancer. However, more clinical studies are needed prior introducing of miR-155 in prognosis of cancer. In targeted therapy underexpressed miRNAs may be replenished by the administration of miRNA mimetics, whereas overexpressed miRNAs can be targeted by a novel class of synthetic oligonucleotides known as antagomirs.

Given that miR-155-5p overexpression appears to play a pathophysiological role in a number of disease processes, a decrease in the in vivo concentration of this miRNA would thereby derepress expression of its targets. The levels of the aberrantly over-expressed miRNAs can be reduced through the use of antimiRs (miRNA inhibitors) harboring the full or partial complementary reverse sequence of a mature miRNA [97]. Several recent studies have demonstrated utilization of miR-155-5p antimiR inhibitors to efficiently mediate in vivo miR-155-5p attenuation and target de-repression in mice [98, $99,100,101,102,103,104,105]$. However, systemic delivery of these modulators may not be a preferred approach due to the pleiotropic effect of miRNA on gene expression. Therefore, organ specific delivery of miRNA inhibitors/modulators remains a major challenge. With the advancement of RNA delivery technology, it is anticipated that miRNA-based therapeutics will become the latest challenge in human cancer treatment.

Table 1. List of 11 selected relevant studies on hematomalignancies and solid tumors focused on hazard ratio (HR) and prognostic value of miR-155. Of these, 5 lack of HR data. PDAC, pancreatic ductal adenocarcinoma; CLL, chronic lymphocytic leukemia; DLBCL, diffuse large B cell lymphoma; qRT-PCR, quantitative real-time PCR; OS, overall survival; DFS, disease-free survival; TSF, treatment-free survival; SC, survival curve. (Adopted and modified from $\mathrm{He}$ et al., 2013.)

\begin{tabular}{|c|c|c|c|c|c|c|c|}
\hline Author & $\begin{array}{c}\text { Population } \\
\text { origin }\end{array}$ & Disease & $\mathbf{N}$ & miR-155 assay & $\begin{array}{l}\text { Survival } \\
\text { analysis }\end{array}$ & HR statistics & $\begin{array}{c}\text { Follow-up, } \\
\text { months }\end{array}$ \\
\hline Chen 2011 & China & breast cancer & 92 & RT-PCR & OS,DFS & SC & 60 \\
\hline Greither 2010 & Germany & PDAC & 55 & qRT-PCR & OS & reported & $15.9(1-61)$ \\
\hline Ishihara 2012 & Japan & leukemia & 35 & qRT-PCR & OS & $\mathrm{SC}$ & 33 \\
\hline Papaconstantinou 2012 & Greece & PDAC & 88 & qRT-PCR & OS & SC & 78 \\
\hline Rossi 2010 & USA & CLL & 104 & qRT-PCR & OS, TFS & reported & 160 \\
\hline Shibuya 2010 & Japan & $\begin{array}{l}\text { colorectal } \\
\text { cancer }\end{array}$ & 156 & qRT-PCR & OS,DFS & reported & 60 \\
\hline Kong 2011 & China & PDAC & 35 & qRT-PCR & & - & \\
\hline Lawrie 2007 & UK & DLBCL & 76 & qRT-PCR & & - & \\
\hline Lawrie 2008 & UK & DLBCL & 60 & $\begin{array}{l}\text { qRT-PCR, } \\
\text { serum }\end{array}$ & & - & \\
\hline Sun 2012 & China & breats cancer & 103 & $\begin{array}{l}\text { qRT-PCR, } \\
\text { serum }\end{array}$ & & - & \\
\hline Wang 2010 & China & acute leukemia & 85 & qRT-PCR & & - & \\
\hline
\end{tabular}


Babar et al. [98] in their miR-155-5p antimiR inhibitor studies encapsulated a peptide nucleic acid anti-miR-155-5p inhibitor in poly(lactic-co-glycolic acid) (PLGA) nanoparticles that were decorated with the cell-penetrating peptide, penetratin. These nanoparticles uniquely favored the delivery of their anti-miR-155-5p cargo into pre-B cells. In a nanoparticle treated transgenic lymphoma mouse model, an in vivo antimiR-155-5p delivery lead to lymphoid tumor growth delay [98]. This strategy offers a promising therapeutic approach for the treatment of lymphoma/leukemia. antimiR inhibitor therapy may be useful in treating diseases mediated by the overexpression of miR-155-5p.

Zhang and coworkers summarized novel technical approaches to gain-of-function and loss-of-function manipulation of miRNA expression in vitro and in vivo and its targeted delivery and highlight their advantages and disadvantages [106]. In common, miRNAs hold a promise to be developed into novel biomarkers with clinical implications as diagnostic, treatment monitoring and prognostic markers as well as very promising therapeutically targets.

Acknowledgements: This work was supported by grant co-sponsored by sources of EU - European fond for regional development through operation program of Research and Development (project code ITMS 26240220074 / call code OPVaV-2011/4.2/07-SORO). In addition, the present work was supported by the Slovak Research and Development Agency (APVV-0016-11).

\section{References}

[1] HONG J, ZHANG H, KAWASE-KOGA Y, SUN T. MicroRNA function is required for neurite outgrowth of mature neurons in the mouse postnatal cerebral cortex. Front Cell Neurosci 2013; 7: 151. http://dx.doi.org/10.3389/fncel.2013.00151

[2] COSTINEAN S, ZANESI N, PEKARSKY Y, TILI E, VOLINIA $S$ et al. Pre-B cell proliferation and lymphoblastic leukemia/ high-grade lymphoma in E(mu)-miR155 transgenic mice. Proc Natl Acad Sci USA 2006; 103: 7024-7029. http://dx.doi. org/10.1073/pnas.0602266103

[3] HATFIELD S, RUOHOLA-BAKER H. microRNA and stem cell function. Cell Tissue Res 2008; 331: 57-66. http://dx.doi. org/10.1007/s00441-007-0530-3

[4] CHEN Y, STALLINGS RL. Differential patterns of microRNA expression in neuroblastoma are correlated with prognosis, differentiation, and apoptosis. Cancer Res 2007; 67: 976-983. http://dx.doi.org/10.1158/0008-5472.CAN-06-3667

[5] BALTIMORE D, BOLDIN MP, O'CONNELL RM, RAO DS, TAGANOV KD. MicroRNAs: new regulators of immune cell development and function. Nat Immunol 2008; 9: 839-845. http://dx.doi.org/10.1038/ni.f.209

[6] TRIBOULET R, MARI B, LIN YL, CHABLE-BESSIA C, BENNASSER Y et al. Supression of microRNA-silencing pathway by HIV-1 during virus replication. Science 2007; 315 : 1579-1582. http://dx.doi.org/10.1126/science.1136319

[7] KASINSKI AL, SLACK FJ. Epigenetics and genetics. MicroRNAs en route to the clinic: progress in validating and targeting
microRNAs for cancer therapy. Nat Rev Cancer 2011; 11: 849-864. http://dx.doi.org/10.1038/nrc3166

[8] ALEVIZOS I, ILLEI GG. MicroRNAs as biomarkers in rheumatic diseases. Nat Rev Rheumatol 2010; 6: 391-398. http://dx.doi.org/10.1038/nrrheum.2010.81

[9] BARTEL DP. MicroRNAs: Target recognition and regulatory functions. Cell 2009; 136: 215-233. http://dx.doi.org/10.1016/ j.cell.2009.01.002

[10] KRUTZFELDT J, STOFFEL M. MicroRNAs: a new class of regulatory genes affecting metabolism. Cell Metab 2006; 4: 9-12. http://dx.doi.org/10.1016/j.cmet.2006.05.009

[11] FRIEDMAN RC, FARH KK, BURGE CB, BARTEL DP. Most mammalian mRNAs are conserved targets of microRNAs. Genome Res 2009; 1: 92-105.

[12] DOMBKOWSKI AA, SULTANA Z, CRAIG DB, JAMIL H. In silico analysis of combinatorial microRNA activity reveals target genes and pathways associated with breast cancer metastasis. Cancer Inform 2011; 10: 13-29. http://dx.doi. org/10.4137/CIN.S6631

[13] FORREST AR, KANAMORI-KATAYAMA M, TOMARU Y, LASSMANN T, NINOMIYA $\mathrm{N}$ et al. Induction of microRNAs, mir-155, mir-222, mir-424 and mir-503, promotes monocytic differentiation through combinatorial regulation. Leukemia 2010; 24: 460-466. http://dx.doi.org/10.1038/ leu.2009.246

[14] KROL J, LOEDIGE I, FILIPOWICZ W. The widespread regulation of microRNA biogenesis, function and decay. Nat Rev Genet 2010; 11: 597-610.

[15] FABIAN MR, SONENBERG N. The mechanics of miRNA mediated gene silencing: a look under the hood of miRISC. Nat Struct Mol Biol 2012; 19: 586-593. http://dx.doi.org/10.1038/ $\underline{\text { nsmb.2296 }}$

[16] CHENDRIMADA TP, GREGORY RI, KUMARASWAMY E, NORMAN J, COOCH N et al. TRBP recruits the Dicer complex to Ago 2 for microRNA processing and gene silencing. Nature 2005; 436: 740-744. http://dx.doi.org/10.1038/ nature 03868

[17] FILIPOWICZ W, BHATTACHARYYA SN, SONENBERG N. Mechanisms of post-transcriptional regulation by microRNAs: are the answers in sight? Nat Rev Genet 2008; 2: 102-114. http://dx.doi.org/10.1038/nrg2290

[18] GRIFFITHS-JONES S. The microRNA registry. Nucleic Acids Res 2004; 32: D109-D111. http://dx.doi.org/10.1093/nar/ gkh023

[19] RUEGGERS, GROSSHANS H. MicroRNA turnover: when, how, and why. Trends Biochem Sci 2012; 37: 436-446. http:// dx.doi.org/10.1016/j.tibs.2012.07.002

[20] GRIMSON A, FARH KKH, JOHNSTON WK, GARRETTENGELE P, LIM LP et al. MicroRNA targeting specificity in mammals: determinants beyond seed pairing. Mol Cell 2007; 27: 91-105. http://dx.doi.org/10.1016/j.molcel.2007.06.017

[21] CHENDRIMADA TP, KENNETH JF, XINJUN J, BAILLAT D, GREGORY RI et al. MicroRNA silencing through RISC recruitment of eIF6. Nature 2007; 447: 823-828. http://dx.doi. org/10.1038/nature 05841

[22] GUO H, INGOLIA NT, WEISSMAN JS, BARTEL DP. Mammalian microRNAs predominantly act to decrease target 
mRNA levels. Nature 2010; 466: 835-840. http://dx.doi. org/10.1038/nature09267

[23] TAM W. Identification and characterization of human BIC, a gene on chromosome 21 that encodes a noncoding RNA. Gene 2001; 274: 157-167. http://dx.doi.org/10.1016/S03781119(01)00612-6

[24] SHIN C. Cleavage of the star strand facilitates assembly of some microRNAs into Ago2-containing silencing complexes in mammals. Mol Cell 2008; 26: 308-313.

[25] PACKER AN, XING Y, HARPER SQ, JONES L, DAVIDSON BL. The bifunctional microRNA, miR-9/miR-9*, regulates REST and CoREST and is downregulated in Huntington's disease. J Neurosci 2008; 28: 14341-14346. http://dx.doi. org/10.1523/JNEUROSCI.2390-08.2008

[26] YANG JS, PHILLIPS MD, BETEL D, MU P, VENTURA A et al. Widespread regulatory activity of vertebrate microRNA* species. RNA 2011; 17: 312-326. http://dx.doi.org/10.1261/ rna.2537911

[27] ELTONT S, SANSOM SE, MARTIN MM. Trisomy-21 gene dosage overexpression of miRNAs results in the haploinsufficiency of specific target proteins. RNA Biol 2010; 7: 540-547. http://dx.doi.org/10.4161/rna.7.5.12685

[28] TARASSISHIN L, LOUDIG O, BAUMAN A, SHAFIT-ZAGARDO B, SUH HS et al. Interferon regulatory factor 3 inhibits astrocyte inflammatory gene expression through suppression of the proinflammatory miR-155 and miR-155*. Glia 2011; 59: 1911-1922. http://dx.doi.org/10.1002/glia.21233

[29] ZHOU H, HUANG X, CUI H, LUO X, TANG Y et al. miR155 and its star-form partner miR-155* cooperatively regulate type I interferon production by human plasmacytoid dendritic cells. Blood 2010; 116: 5885-5894. http://dx.doi.org/10.1182/ blood-2010-04-280156

[30] MAO CP, HE L, TSAI YC, PENG S, KANG TH et al. In vivo microRNA-155 expression influences antigen-specific $\mathrm{T}$ cell-mediated immune responses generated by DNA vaccination. Cell Biosci 2011; 1: 3. http://dx.doi.org/10.1186/2045-3701-1-3

[31] O`CONNELL RM, TAGANOV KD, BOLDIN MP, CHENG G, BALTIMORE D. MicroRNA-155 is induced during the macrophage inflammatory response. Proc Natl Acad Sci US A 2007; 104: 1604-1609. http://dx.doi.org/10.1073/ pnas.0610731104

[32] GEORGANTAS III RW, HILDRETH R, MORISOT S, ALDER J, LIU C et al. CD34 + hematopoietic stem-progenitor cell microRNA expression and function: a circuit diagram of differentiation control. Proc Natl Acad Sci USA 2007; 104: 2750-2755. http://dx.doi.org/10.1073/pnas.0610983104

[33] MASAKI S, OHTSUKA R, ABE Y, MUTA K, UMEMURA T. Expression patterns of microRNAs 155 and 451 during normal human erythropoiesis. Biochem Biophys Res Commun 2007; 364: 509-514. http://dx.doi.org/10.1016/ j.bbrc.2007.10.077

[34] LANDGRAF P, RUSU M, SHERIDAN R, SEWER A, IOVINO $\mathrm{N}$ et al. A mammalian microRNA expression atlas based on small RNA library sequencing. Cell 2007; 129: 1401-1414. http://dx.doi.org/10.1016/j.cell.2007.04.040

[35] MARTIN MM, LEE EJ, BUCKENBERGER JA, SCHMITTGEN TD, ELTON TS. MicroRNA-155 regulates human angiotensin II type 1 receptor expression in fibroblasts. J Biol Chem 2006; 28: 18277-18284. http://dx.doi.org/10.1074/jbc. M601496200

[36] STANCZYK J, PEDRIOLI DML, BRENTANO F, SANCHEZPERNAUTEO, KOLLING C et al. Altered expression of microRNA in synovial fibroblasts and synovial tissue in rheumatoid arthritis. Arthritis Rheum 2008; 58: 1001-1009. http://dx.doi.org/10.1002/art.23386

[37] KONG W, YANG H, HE L, ZHAO JJ, COPPOLA D et al. MicroRNA-155 is regulated by the transforming growth factor beta/Smad pathway and contributes to epithelial cell plasticity by targeting RhoA. Mol Cell Biol 2008; 28: 6773-84. http://dx.doi.org/10.1128/MCB.00941-08

[38] YIN Q, MCBRIDE J, FEWELL C, LACEY M, WANG X et al. MicroRNA-155 is an Epstein-Barr virus-induced gene that modulates Epstein-Barr virus-regulated gene expression pathways. J Virol 2008; 82: 5295-5306. http://dx.doi. org/10.1128/JVI.02380-07

[39] JIANGJ, LEE EJ, SCHMITTGEN TD. Increased expression of microRNA-155 in Epstein-Barr virus transformed lymphoblastoid cell lines. Genes Chromosomes Cancer 2006; 45: 103-106. http://dx.doi.org/10.1002/gcc.20264

[40] KLUIVERJ, HARALAMBIEVA E, DE JONG D, BLOKZIJL T, JACOBS $S$ et al. Lack of BIC and microRNA miR-155 expression in primary cases of Burkitt lymphoma. Genes Chromosomes Cancer 2006; 45: 147-153. http://dx.doi. org/10.1002/gcc.20273

[41] LINNSTAEDT SD, GOTTWEIN E, SKALSKY RL, LUFTIG MA, CULLEN BR. Virally induced cellular microRNA miR-155 plays a key role in B-cell immortalization by Epstein-Barr virus. J Virol 2010; 84: 11670-11678. http://dx.doi. org/10.1128/JVI.01248-10

[42] GATTO G, ROSSI A, ROSSI D, KROENING S, BONATTI $S$ et al. Epstein-Barr virus latent membrane protein 1 transactivates miR-155 transcription through the NF-kappaB pathway. Nucleic Acids Res 2008; 36: 6608-6619. http://dx.doi. org/10.1093/nar/gkn666

[43] WANG L, TOOMEY NL, DIAZ LA, WALKER G, RAMOS JC et al. Oncogenic IRFs provide a survival advantage for Epstein-Barr virus- or human T-cell leukemia virus type 1-transformed cells through induction of BIC expression. J Virol 2011; 85: 8328-8337. http://dx.doi.org/10.1128/ JVI.00570-11

[44] CREMER TJ, RAVNEBERG DH, CLAY CD, PIPER-HUNTER MG, MARSH CB et al. MiR-155 induction by F. novicida but not the virulent $\mathrm{F}$. tularensis results in SHIP down-regulation and enhanced pro-inflammatory cytokine response. PLoS One 2009; 4: e8508 http://dx.doi.org/10.1371/journal.pone.0008508

[45] O'CONNELL RM, CHAUDHURI AA, RAO DS, BALTIMORE D. Inositol phosphatase SHIP1 is a primary target of miR-155. Proc Natl Acad Sci U SA 2009; 106: 7113-7118. http://dx.doi. org/10.1073/pnas.0902636106

[46] VARGOVA K, CURIK N, BURDA P, BASOVA P, KULVAIT $\mathrm{V}$ et al. MYB transcriptionally regulates the miR-155 host gene in chronic lymphocytic leukemia. Blood 2011; 117: 3816-3825. http://dx.doi.org/10.1182/blood-2010-05$\underline{285064}$ 
[47] EIS PS, TAM W, SUN L, CHADBURN A, LI Z et al. Accumulation of miR-155 and BIC RNA in human B cell lymphomas. Proc Natl Acad Sci USA 2005; 102: 3627-3632. http://dx.doi. org/10.1073/pnas.0500613102

[48] FULCI V, CHIARETTI S, GOLDONI M, AZZALIN G, CARUCCI N et al. Quantitative technologies establish a novel microRNA profile of chronic lymphocytic leukemia. Blood 2007; 109: 4944-4951. http://dx.doi.org/10.1182/blood-200612-062398

[49] KLUIVER J, POPPEMA S, DE JONG D, BLOKZIJL T, HARMS G et al. BIC and miR-155 are highly expressed in Hodgkin, primary mediastinal and diffuse large B cell lymphomas. J Pathol 2005; 207: 243-249. http://dx.doi. org/10.1002/path.1825

[50] O'CONNELL RM, RAO DS, CHAUDHURI AA, BOLDIN MP, TAGANOV KD et al. Sustained expression of microRNA155 in hematopoietic stem cells causes a myeloproliferative disorder. J Exp Med 2008; 205: 585-594. http://dx.doi.org/ 10.1084/jem.20072108

[51] RAMKISSOON SH, MAINWARINGC LA, OGASAWARAC Y, KEYVANFARC K, MCCOY JRC JP et al. Hematopoieticspecific microRNA expression in human cells. Leuk Res 2006; 30: 643-647. http://dx.doi.org/10.1016/ j.leukres.2005.09.001

[52] THOMPSON RC, HERSCOVITCH M, ZHAO I, FORD TJ, GILMORE TD. NF-kappaB down-regulatesexpressionoftheBlymphoma marker CD10 through a miR-155/PU.1 pathway. J Biol Chem 201; 286: 1675-1682.

[53] VAN DEN BERG A, KROESEN BJ, KOOISTRA K, DE JONG D, BRIGGS J et al. High expression of B-cell receptor inducible gene BIC in all subtypes of Hodgkin lymphoma. Genes Chromosom Cancer 2003; 37: 20-28. http://dx.doi. org/10.1002/gcc. 10186

[54] RAHADIANI N, TAKAKUWA T, TRESNASARI K, MORII E, AOZASA K. Latent membrane protein-1 of Epstein-Barr virus induces the expression of $\mathrm{B}$-cell integration cluster, a precursor form of microRNA-155, in B lymphoma cell lines. Biochem Biophys Res Commun 2008; 377: 579-83. http://dx.doi.org/10.1016/j.bbrc.2008.10.007

[55] CALIN GA, CROCE CM. Chronic lymphocytic leukemia: interplay between noncoding RNAs and protein-coding genes. Blood 2009; 114: 4761-4770. http://dx.doi.org/10.1182/blood2009-07-192740

[56] MRAZ M, POSPISILOVA S, MALINOVA K, SLAPAK I, MAYER J. MicroRNAs in chronic lymphocytic leukemia pathogenesis and disease subtypes. Leuk Lymphoma 2009; 50: 506-509. http://dx.doi.org/10.1080/10428190902763517

[57] KAUFMAN M, RUBIN J, RAI K. Diagnosing and treating chronic lymphocytic leukemia in 2009. Oncology 2009; 23: 1030-1037.

[58] OVCHARENKO D, KELNAR K, JOHNSON C, LENG N, BROWN D. Genome-scale microRNA and small interfering RNA screens identify small RNA modulators of TRAIL-induced apoptosis pathway. Cancer Res 2007; 67: 10782-10788. http://dx.doi.org/10.1158/0008-5472.CAN-07-1484

[59] GIRONELLA M, SEUX M, XIE MJ, CANO C, TOMASINI R et al. Tumor protein 53 -induced nuclear protein 1 expression is repressed by miR-155, and its restoration inhibits pancreatic tumor development. Proc Natl Acad Sci US A 2007; 104: 16170-16175. http://dx.doi.org/10.1073/pnas.0703942104

[60] DORSETT Y, MCBRIDE KM, JANKOVIC M, GAZUMYAN A, THAI TH et al. MicroRNA-155 suppresses activation-induced cytidinedeaminase-mediated Myc-Igh translocation. Immunity 2008; 28: 630-638. http://dx.doi.org/10.1016/ j.immuni.2008.04.002

[61] MUTO T, OKAZAKI IM, YAMADA S, TANAKA Y, KINOSHITA K. Negative regulation of activation-induced cytidinedeaminase in B cells. Proc Natl Acad Sci USA 2006; 103: 2752-2757. http://dx.doi.org/10.1073/pnas.0510970103

[62] DE YEBENES VG, BELVER L, PISANO DG, GONZALEZ S, VILLASANTE A et al. miR-181b negatively regulates activation-induced cytidinedeaminase in B cells. J Exp Med 2008; 205: 2199-2206. http://dx.doi.org/10.1084/ jem.20080579

[63] ALENCAR AJ, MALUMBRES R, KOZLOSKI GA, ADVANI $\mathrm{R}$, TALREJA $\mathrm{N}$ et al. MicroRNAs are independent predictors of outcome in diffuse large B-cell lymphoma patients treated with R-CHOP. Clin Cancer Res 2011; 17: 4125-4135. http:// dx.doi.org/10.1158/1078-0432.CCR-11-0224

[64] RAI D, KIM SW, MCKELLER MR, DAHIA PL, AGUIAR RC. Targeting of SMAD5 links microRNA-155 to the TGF-beta pathway and lymphomagenesis. Proc Natl Acad Sci USA 2010; 107: 3111-3116. http://dx.doi.org/10.1073/ pnas.0910667107

[65] HUANG X, SHEN Y, LIU M, BI C, JIANG C. Quantitative proteomics reveals that miR-155 regulates the PI3K-AKT pathway in diffuse large B-cell lymphoma. Am J Pathol 2012; 181: 26-33. http://dx.doi.org/10.1016/j.ajpath.2012.03.013

[66] PEDERSEN IM, OTERO D, KAO E, MILETIC AV, HOTHER C. Onco-miR-155 targets SHIP1 to promote TNFalpha-dependent growth of B cell lymphomas. EMBO Mol Med 2009; 1: 288-295. http://dx.doi.org/10.1002/ emmm.200900028

[67] COMPAGNO M, LIM WK, GRUNN A, NANDULA SV, BRAHMACHARY $\mathrm{M}$ et al. Mutations of multiple genes cause deregulation of NF-kappaB in diffuse large B-cell lymphoma. Nature 2009; 459: 717-721. http://dx.doi.org/ $10.1038 /$ nature 07968

[68] HUI ABY, SHI W, BOUTROS PC, MILLER N, PINTILIE M et al. Robust global micro-RNA profiling with formalin-fixed paraffin-embedded breast cancer tissues. Lab Invest 2009: 89: 597-606. http://dx.doi.org/10.1038/labinvest.2009.12

[69] KONGW, HE L, COPPOLA M, GUO J, ESPOSITO NN et al. MicroRNA-155 regulates cell survival, growth, and chemosensitivity by targeting FOXO3a in breast cancer. J Biol Chem 2010; 285: 17869-17879. http://dx.doi.org/10.1074/jbc. M110.101055

[70] VOLINIA S, CALIN GA, LIU CG, AMBSS, CIMMINO A et al. A microRNA expression signature of human solid tumors defines cancer gene targets. Proc Natl Acad Sci USA 2006; 103: 2257-2261. http://dx.doi.org/10.1073/pnas.0510565103

[71] LEE EJ, GUSEV Y, JIANG J, NUOVO GJ, LERNER MR et al. Expression profiling identifies microRNA signature in pancreatic cancer. Int. J Cancer 2007; 120: 1046-1054. 
[72] SZAFRANSKA AE, DAVISON TS, JOHN J, CANNON T, SIPOS B et al. MicroRNA expression alterations are linked to tumorigenesis and nonneoplastic processes in pancreatic ductal adenocarcinoma. Oncogene 2007; 26: 4442-4452. http://dx.doi.org/10.1038/sj.onc.1210228

[73] WANG X, TANG S, LE SY, LU R, RADER JS et al. Aberrant expression of oncogenic and tumor-suppressive microRNAs in cervical cancer is required for cancer cell growth. PLoS One 2008; 3: 2557. http://dx.doi.org/10.1371/journal.pone.0002557

[74] JAY C, NEMUNAITIS J, CHEN P, FULGHAM P, TONG AW. MiRNA profiling for diagnosis and prognosis of human cancer. DNA Cell Biol 2007; 26: 293-300. http://dx.doi. org/10.1089/dna.2006.0554

[75] NIKIFOROVA MN, TSENG GC, STEWARD D, DIORIO D, NIKIFOROV YE. MicroRNA expression profiling of thyroid tumors: biological significance and diagnostic utility. J Clin Endocrinol Metab 2008; 93: 1600-1608. http://dx.doi. org/10.1210/jc.2007-2696

[76] MATTISKE S, SUETANI RJ, NEILSEN PM, CALLEN DF. The Oncogenic Role of miR-155 in Breast Cancer. Cancer Epidemiol Biomarkers Prev 2012; 21: 1236-1243. http://dx.doi. org/10.1158/1055-9965.EPI-12-0173

[77] CHANG S, WANG RH, AKAGI K, KIM KA, MARTIN BK et al. Tumor suppressor BRCA1 epigenetically controls oncogenic microRNA-155. Nat Med 2011; 17: 1275-1282. http://dx.doi.org/10.1038/nm.2459

[78] YARDEN RI, BRODY LC.BRCA1 interacts with components of the histone deacetylase complex. Proc Natl Acad Sci USA 1999; 96: 4983-4988. http://dx.doi.org/10.1073/ pnas.96.9.4983

[79] NEILSEN PM, NOLL JE, MATTISKE S, BRACKEN CP, GREGORY PA et al. Mutant p53 drives invasion in breast tumors through up-regulation of miR-155. Oncogene 2012a; 32: 2992-3000.

[80] JIANG S, ZHANG HW, LU MH, HE XH, LI Y et al. MicroRNA-155 functions as an OncomiR in breast cancer by targeting the suppressor of cytokine signaling 1 gene. Cancer Res 2010; 70: 3119-3127. http://dx.doi.org/10.1158/00085472.CAN-09-4250

[81] ADORNO M, CORDENONSI M, MONTAGNER M, DUPONT S, WONG C et al. A mutant-p53/Smad complex opposes p63 to empower TGF2-induced metastasis. Cell 2009; 137: 87-98. http://dx.doi.org/10.1016/j.cell.2009.01.039

[82] MULLER PAJ, CASWELL PT, DOYLE B, IWANICKI MP, TAN EH et al. Mutant p53 drives invasion by promoting integrin recycling. Cell 2009; 139: 1327-1341. http://dx.doi. org/10.1016/j.cell.2009.11.026

[83] MCINNES N, SADLON TJ, BROWN CY, PEDERSON S, BEYER $M$ et al. FOXP3 and FOXP3-regulated microRNAs suppress SATB1 in breast cancer cells. Oncogene 2012; 31: 1045-1054. http://dx.doi.org/10.1038/onc.2011.293

[84] LADOIRE S, ARNOULD L, MIGNOT G, COUDERT B, REBE $\mathrm{C}$ et al. Presence of Foxp3 expression in tumor cells predicts better survival in HER2-overexpressing breast cancer patients treated with neoadjuvant chemotherapy. Breast Cancer Res Treat 2011; 125: 65-72. http://dx.doi.org/10.1007/s10549$\underline{010-0831-1}$
[85] ZUO T, LIU R, ZHANG H, CHANG X, LIU Y et al. FOXP3 is a novel transcriptional repressor for the breast cancer oncogene SKP2. J Clin Invest 2007; 117: 3765-3773.

[86] WU WK, LAW PT, LEE CW, CHO CH, FAN D. MicroRNA in colorectal cancer: from benchtop to bedside. Carcinogenesis 2011; 32:247-253. http://dx.doi.org/10.1093/ carcin/bgq 243

[87] FALTEJSKOVA P, SVOBODA M, SRUTOVA K, MLCOCHOVA J, BESSE A et al. Identification and functional screening of microRNAs highly deregulated in colorectal cancer. J Cell Mol Med 2012; 16: 2655-2666. http://dx.doi.org/10.1111/j.15824934.2012.01579.x

[88] SHIBUYA H, IINUMA H, SHIMADA R, HORIUCHI A, WATANABE T. Clinicopathological and prognostic value of microRNA-21 and microRNA-155 in colorectal cancer. Oncology 2010; 79: 313-20. http://dx.doi.org/10.1159/ 000323283

[89] SINGH AK, PANDEY R, GILL K, SINGH R, SARAYA A. p38 $\beta$ MAP kinase as a therapeutic target for pancreatic cancer. Chem Biol Drug Des 2012; 80: 266-273. http://dx.doi. org/10.1111/j.1747-0285.2012.01395.x

[90] BUSHATI N, COHEN SM. MicroRNA functions. Annu Rev Cell Dev Biol 2007; 23: 175-205. http://dx.doi.org/10.1146/annurev.cellbio.23.090506.123406

[91] KUHN DE, MARTINE MM, FELDMANC DS, TERRY JR. AV, NUOVO GJ et al. Experimental validation of miRNA targets. Methods 2008; 44: 47-54. http://dx.doi.org/10.1016/ j.ymeth.2007.09.005

[92] NIELSEN BS. MicroRNA in situ hybridization. Methods Mol Biol 2012b; 822: 67-84.

[93] ELTON TS, SELEMON H, ELTON SM, PARINANDI NL. Regulation of the MIR155 host gene in physiological and pathological processes. Gene 2012; S0378-1119: 01512-0.

[94] QI J, WANG J, KATAYAMA H, SEN S, LIU SM. Circulating microRNAs (cmiRNAs) as novel potential biomarkers for hepatocellular carcinoma. Neoplasma 2013; 60: 135-142. http://dx.doi.org/10.4149/neo 2013018

[95] SLABY O, LAKOMY R, FADRUS P, HRSTKA R, KREN L et al. MicroRNA-181 family predicts response to concomitant chemoradiotherapy with temozolomide in glioblastoma patients. Neoplasma 2010; 57: 264-269. http://dx.doi.org/ $10.4149 /$ neo $2010 \quad 03 \quad 264$

[96] HE J, ZHANG F, WU Y, ZHANG W, ZHU X et al. Prognostic role of microRNA-155 in various carcinomas: results from a meta-analysis. Dis Markers 2013; 34: 379-386. http://dx.doi. org $/ 10.1155 / 2013 / 856750$

[97] VAN ROOIJ E, PURCELL AL, LEVIN AA. Developing microRNA therapeutics. Circ Res 2012; 110: 496-507. http://dx.doi. org/10.1161/CIRCRESAHA.111.247916

[98] BABARIA, CHENGB CJ, BOOTHD CJ, LIANGAX, WEIDHAASE JB et al. Nanoparticle-based therapy in an in vivo microRNA-155 (miR-155)-dependent mouse model of lymphoma. Proc Natl Acad Sci USA 2012; 109: E1695-E1704. http://dx.doi.org/10.1073/pnas.1201516109

[99] CORSTENMF, PAPAGEORGIOU A, VERHESEN W, CARAI P, LINDOW $\mathrm{M}$ et al. MicroRNA profiling identifies microRNA-155 as an adverse mediator of car- 
diac injury and dysfunction during acute viral myocarditis. Circ Res 2012; 11: 415-425. http://dx.doi.org/10.1161/ CIRCRESAHA.112.267443

[100] FABANI MM, ABREU-GOODGER C, WILLIAMS D, LYONS PA, TORRES AG et al. Efficient inhibition of miR-155 function in vivo by peptide nucleic acids. Nucleic Acids Res 2010; 38: 4466-4475. http://dx.doi.org/10.1093/nar/gkq160

[101] KUHN DE, NUOVO GJ, TERRY JR. AV, MARTIN MM, MALANA GE et al. Chromosome 21-derived miRNAs provide an etiological basis for aberrant protein expression in human Down syndrome brains. J Biol Chem 2010; 285: 1529-1543. http://dx.doi.org/10.1074/jbc.M109.033407

[102] MURUGAIYAN G, BEYNON V, MITTAL A, JOLLER N, WEINER HL. Silencing microRNA-155 ameliorates experimental autoimmune encephalomyelitis. J Immunol 2011; 187: 2213-2221. http://dx.doi.org/10.4049/jimmunol.1003952
[103] RANGANATHAN P, HEAPHY CEA, COSTINEAN S, STAUFFER N, NA C et al. Regulation of acute graft-versushost disease by microRNA-155. Blood 2012; 119: 4786-4797. http://dx.doi.org/10.1182/blood-2011-10-387522

[104] WORM J, STENVANG J, PETRI A, FREDERIKSEN KS, OBAD $S$ et al. Silencing of microRNA-155 in mice during acute inflammatory response leads to derepression of c/ebp Beta and down-regulation of G-CSF. Nucl Acids Res 2009; 37: 5784-5792. http://dx.doi.org/10.1093/nar/gkp577

[105] ZHANG Y, ROCCARO AM, ROMBA OA C, FLORES L, OBAD $S$ et al. LNA-mediated anti-miR-155 silencing in low-grade B-cell lymphomas. Blood 2012; 120: 1678-1686. http://dx.doi.org/10.1182/blood-2012-02-410647

[106] ZHANG H, SHYKIND B, SUN T. Approaches to manipulating microRNAs in neurogenesis. Front Neurosci 2013; 6: 196. http://dx.doi.org/10.3389/fnins.2012.00196 